\title{
Poverty and Culture
}

\author{
Lawrence M. Mead
}

Editor's note: this article was originally published in SOCIETY: Social Science and Modern Society $(J u l y ~ 21,2020)$ under the same title. It was retracted on July 21, 2020 by the publisher Springer under pressure from activists, advocates, and scholars who believe, apparently, that examining cultural habits, beliefs, and attitudes as it relates to the socio-economic mobility of various groups is racist. Despite decades of research by renowned scholars as different in their political viewpoints as Nathan Glazer and Oscar Lewis indicating that all groups that have joined America's expansive middle-class have assimilated, to one degree or another, certain cultural traits, one petition by the aggrieved professors excoriates Mead for perpetuating "the racist ideology of assimilation."

The cause and nature of long-term poverty is one of the most important yet daunting questions scholars have tried to address in the modern era. Despite what the petitioners against Mead's article imply, there is no consensus about the causes of poverty and even less agreement on the efficacy of various solutions. The editors of Academic Questions and the National Association of Scholars believe that the best approach to difficult policy questions is the free flow of ideas from a large variety of viewpoints and methodologies. It is true that we know Professor Mead as a man of great personal integrity. But we publish his account here because we believe the problem of poverty, like other scholarly questions, benefits most from free and rigorous debate and careful consideration of the evidence. It is disappointing to see large numbers of scholars seek to close off viewpoints they disagree with and to shut down debate (while also seeking to personally damage and impugn a fellow scholar). It is even more dispiriting to watch as respected publishers and academic institutions comply with such obvious attacks on academic freedom. In republishing Mead's article we uphold the principles of academic freedom, including the freedom of faculty members to pursue academic research; their freedom to question and to think for themselves; and their freedom from ideological imposition.

\section{Introduction}

America has long prided itself on turning poverty into plenty. People who came here from other lands set out to achieve the "American dream," and many have done so. At least they realized some gains in their own status and income, and many saw their children do even better. By the official poverty measure, 22 percent of Americans were poor in 1959, only 12 percent in 2018, so there clearly has been progress.

Yet, the most serious poverty is still with us, and in some ways is getting worse. Most of those who are poor in a given year escape quickly, often by getting a job or recovering from illness or family breakup. More worrisome are those-perhaps half of all poor-who suffer poverty for two or more years at a stretch. While this number appears small, it includes many of America's 
most troubled families and also poor men, many of whom are absent fathers or ex-offenders.

Recent decades have seen progress in reducing crime, welfare, and pregnancy among teens, yet we are still far from restoring order to low-income neighborhoods. Marriage remains in steep decline, poor children still do poorly in school, and work levels among poor adults-both men and women-remain well below what they need to avoid poverty.

\section{The Poverty Mystery}

Long-term poverty remains a policy failure, but above all a puzzle. Why do so many Americans remain destitute in the midst of the world's richest country, even when jobs are available? Most poverty arises in the first instance from poor adults not working or from having children outside marriage and then failing to support them-but what explains these patterns? Policymakers continue to invent new programs to help poor families and entice more adults to work, but the positive effects are small at best. Why the needy often lead unproductive lives even when opportunity beckons, and even when help is offered, remains deeply mysterious.

Simple answers failed long ago. Some have thought that the seriously poor simply rejected middle-class values. They tried to live liberated lives like some movie stars in Hollywood-abandoning families or getting high on drugs - to their own cost. ${ }^{1}$ But their professed values do not appear to differ from the mainstream. Many experts also thought that "social barriers" of some impersonal kind were preventing adults from working-such as racial bias, absence of skills or child care, and so on. But no such clear impediment has been found. True, government benefits can raise income among the poor or help them cope-but none causes them to do much more to help themselves. External impediments are not their main problem. ${ }^{2}$

1 Myron Magnet, The Dream and the Nightmare: The Sixties' Legacy to the Underclass (New York: William Morrow, 1993); Christopher Jencks, Rethinking Social Policy: Race, Poverty, and the Underclass (Cambridge, MA: Harvard University Press, 1992).

2 Lawrence M. Mead, The New Politics of Poverty: The Nonworking Poor in America (New York: Basic Books, 1992). 


\section{Cultural Difference}

Research on poverty has mostly assumed that the poor are no different personally from other people, just less fortunate in the opportunities they have. But the failure of many programs has driven some scholars to turn to culture as a cause. Maybe the poor simply think about life differently from the better off. Their goals and values may not differ, but their actual lives diverge far more from those norms than the lives of the better-off.

One version of this kind of thinking is "culture of poverty." In William J. Wilson's “mismatch" theory, for instance, the main reason for urban poverty is lack of adequately paid jobs for the unskilled in the inner city. But Wilson notes that discouragement about work also promotes dysfunctional lifestyles where disadvantaged men decline regular jobs and mothers refuse to marry them, producing troubled families and other ills. ${ }^{3}$ A more pessimistic version, associated with Oscar Lewis, is that the poor have experienced defeat, not just in their own lives, but over many generations past. So they see little hope and settle for erratic work and disordered family lives. ${ }^{4}$ In both these versions, values are orthodox, but poverty occurs due to adversity and defeatism.

A more persuasive version of culture of poverty, however, speaks of cultural difference. It emerges from research on differences in world cultures-a literature hitherto ignored by poverty researchers. Scholars such as Geert Hofstede, Richard Nisbett, and Ronald Inglehart and his associates have shown that rich Western countries differ substantially from the non-West in what most people think life is about. The reason is not centrally that the West is more fortunate, although it is. Rather, the West has evolved a more ambitious lifestyle than the non-West, and it did so long before it became rich. Indeed, it became rich largely because of this confident, enterprising way of life.

In the West most people are individualists. That is, they view life as a project. They focus on their own inner goals and values-such as achieving the American dream-and they seek to realize these out in the world. So their lives flow from the inside out. In the non-West, however, a more cautious and collective mindset usually prevails. Most people have little sense that they are

3 William Julius Wilson, The Truly Disadvantaged: The Inner City, the Underclass, and Public Policy (Chicago: University of Chicago Press, 1987); When Work Disappears: The World of the New Urban Poor (New York: Knopf, 1996).

4 Oscar Lewis, "The Culture of Poverty," in On Understanding Poverty: Perspectives from the Social Sciences, ed. Daniel P. Moynihan (New York: Basic Books, 1969), chap. 7. 
separate from society, and they primarily seek to adjust to the demands made by the outside world, rather than seeking change. The chief goal is simply survival, not advancement. So life flows from the outside in. This general contrast holds true despite the great diversity of cultures in both the West and non-West. ${ }^{5}$

A second major contrast is that the West tends to be moralistic about ethics, while the non-West is more conformist. Westerners typically understand right and wrong as principles that are general and abstract, valid in all times and places. They internalize these norms-such as telling the truth, keeping promises, and obeying the law-as children and then apply them to themselves, other people, and government in later life. In the non-West, however, ethics are more situational and dependent on context. People mostly understand right and wrong in terms of what the people around them expect of them. So there is less sense of absolute standards and less sense of individualized responsibility.

Note especially that this is not a racial argument. Culture is not a euphemism for race. The differences between Western and non-Western culture have nothing to do with race in any physical sense. Rather, they arise from differences in how groups and societies are socialized. Persons of any race may exhibit either Western or non-Western culture, and culture can change over time.

In this reading, cultural difference need not mean that the poor have been disheartened by America. Rather, the West has simply chosen a more ambitious way of life than the non-West, where minorities originate. That difference emerged long ago, even in the Middle Ages. An enterprising temperament, historians suggest, chiefly explains why the West has dominated the globe in recent centuries. Individualism led to constant change and improvements, then to unparalleled wealth, and finally to world power. ${ }^{6}$ While some Asian countries have recently become richer and more powerful themselves, their way of life is collective, not individualist. The impetus to change has come largely from leaders. In the West innovation has been much more broadly based. The whole society is more dynamic.

5 Geert Hofstede, Culture's Consequences: International Differences in Work-Related Values (Newbury Park, CA: Sage, 1980); Richard E. Nisbett, The Geography of Thought: How Asians and Westerners Think Differently... and Why (New York: Free Press, 2003); Ronald Inglehart and Christian Welzel, Modernization, Cultural Change, and Democracy: The Human Development Sequence (New York: Cambridge University Press, 2005).

6 Eric Jones, The European Miracle: Environments, Economics and Geopolitics in the History of Europe and Asia, 3rd ed. (Cambridge, England: Cambridge University Press, 2003; 1st ed. 1981, 2nd ed. 1987); William H. McNeill, The Rise of the West: A History of the Human Community, With a Retrospective Essay (Chicago: University of Chicago Press, 1991; 1st published 1963). 


\section{An Individualist Nation}

These differences go far to explain America's social problems today. Our nation was founded largely by individualists from Europe. Indeed, it was formed mostly by British Protestants who were particularly inner-driven and moralistic. While later immigrants were more diverse, including many Catholics and Jews, they were nearly all Europeans and thus individualists. So from the Founding, Americans have assumed that their assertive and moralistic temperament was normal and universal. But individualism was never uncontested. Even at the Founding, the United States included many people from non-Western origins-Native Americans and Mexicans absorbed by the nation's westward expansion, and above all a large slave population in the South imported from Africa.

Today, the seriously poor are mostly blacks and Hispanics, and the main reason is cultural difference. The great fact is that these groups did not come from Europe. Fifty years after civil rights, their main problem is no longer racial discrimination by white people but rather that they face an individualist culture that they are unprepared for. Their native stance toward life is much more passive than the American norm. In America, they face less hardship than they did where they came from, but also more competition. They now must strive to get ahead in school and the workplace while avoiding crime and personal problems. They also must take much more responsibility for themselves than they did before. In short, they have to become more individualist before they can "make it" in America. They are thus at a disadvantage competing with the European groups-even if they face no mistreatment on racial grounds.

Cultural difference helps to explain the two most puzzling things about the long-term poor: their relatively hesitant response to opportunity and the unusual disorder in their personal lives.

\section{Why Opportunity Fails}

Ever since the War on Poverty, policymakers have presumed that the poor are individualists like everyone else. That implies that they seek to optimize their incomes. So presumably they will be motivated to work and get ahead as soon as government removes the obstacles in their path. Thus, the answer to 
poverty is to expand opportunity. In the 1960s and early 1970s, that worked. At that time, most of the adult poor were employed. Their main problem was simply low wages. So measures to raise wages and break down racial exclusion raised black incomes, often above poverty, and produced a sizable black middle class.

But after that, most of the remaining poor were nonworking, and improving opportunities further did little to raise work levels. Washington, for instance, created training programs designed to raise the skills of disadvantaged workers, so they could get better-paying jobs. But the long-term jobless often turned out to lack even the most basic work discipline. Many simply did not respond to these programs, or they dropped out, or failed to keep jobs once placed. ${ }^{7}$ That pattern still frustrates training efforts today.

A second major strategy was work incentives. Economists reasoned that if low wages were subsidized, work would become more worthwhile and more nonworkers would choose to take jobs. Especially, people drawing welfare had to keep some aid when they took jobs, or the loss of benefits would offset their earnings and deter them from working. But in many experiments, work incentives have never shown much effect on work levels. The Earned Income Tax Credit is often said to have raised employment among poor mothers during welfare reform in the $1990 \mathrm{~s}$, but what it really did was raise the incomes of people already working. ${ }^{8}$ A recent test expansion of EITC to cover single adults without children also showed only small effects, and no significant effect for men at all. ${ }^{9}$

Government on several occasions has simply created jobs for the nonworking poor. But the only clear success came in the late 1970s when jobs were offered to disadvantaged youth; those still in school eagerly took them, although not the school dropouts who were the main concern. ${ }^{10}$ Other job creation programs have either drawn little response at all, or clients who took the jobs did not move on to hold private jobs once the government positions ended. In the New Hope Project, the most remarkable case, low-income adults

$7 \quad$ Lloyd Ulman, "The Uses and Limits of Manpower Policy," The Public Interest (Winter 1974): 83-105.

8 Lawrence M. Mead, "Overselling the Earned Income Tax Credit," National Affairs (Fall 2014): 20-33. Statistical studies often cited to show that EITC raised work levels during welfare reform have been discredited; see Henrik Kleven, "The EITC and the Extensive Margin: A Reappraisal" (Princeton:

Department of Economics and National Bureau of Economic Research, September 2019).

9 Cynthia Miller, Lawrence F. Katz, Gilda Azurdia, Adam Isen, Caroline Schultz, and Kali Aloisi, Boosting the Earned Income Tax Credit for Singles: Final Impact Findings from the Paycheck Plus Demonstration in New York City (New York: MDRC, September 2018).

10 Judith M. Gueron, Lessons From a Job Guarantee: The Youth Incentive Entitlement Pilot Projects (New York: Manpower Demonstration Research Corporation, June 1984) 
in poor areas were offered jobs paying at least the poverty level, plus child and health care. Yet the program struggled even to get enough volunteers to fill its rolls, and those that did participate showed only small work gains. ${ }^{11}$

Cultural difference helps explain what is going on here. The orthodox assumption that the poor are optimizers like other people is often false. That view treats opportunity simply as freedom, simply as the pushing back of outside barriers. To do that may help; the poor may indeed welcome outside help. To take a job, however, implies more than freedom. It means trading the external burdens of poverty for the inner obligations that working entailswhich for many are far heavier. One must now show up on the job every day, take orders, and cooperate with coworkers whether one wants to or not. Outer necessities are replaced by inward responsibilities.

Many non-workers may rather continue a life without commitments, where one works erratically and also gets support from friends, family, or charity. For immigrants who have just escaped Third World hardships for affluent America, life is already much improved. Why attempt more? Better-off Americans have more income, but their lives are filled with responsibilities to others, including families and employers. We call them "privileged," but they are less free in this inner sense than the poor. For many poor adults, the point of life may not be to maximize income.

Some believe that Asian immigrants are an exception. On average, they do well in school, avoid social problems, and get good jobs. How then is nonWestern culture a barrier to success in America? But East Asians, including Chinese, have more trouble succeeding after school. Lacking the individualist style, they have difficulty forming their own goals, leading others, and taking risks, compared to people of European background. So they less often excel in business than either whites or South Asians, who are more assertive. ${ }^{12}$

\section{Why Order Fails}

The other mystery is why social order is much worse in poor areas of America than in better off society. Low-income areas of cities, and some rural

\footnotetext{
11 Lawrence M. Mead, "The Twilight of Liberal Welfare Reform," The Public Interest (Spring 2000), 22 34.

12 "The benefits of being bold," The Economist, February 29, 2020, 53.
} 
areas, suffer from high levels of single female-headed families, welfarism, crime, substance abuse, and failing schools. By some accounts, these problems have risen in recent decades even as economic poverty has fallen. ${ }^{13}$ In the orthodox view, the problems are all due to lack of the resources and other advantages enjoyed by the middle class. The trouble with this view, however, is that American cities were never this troubled a century or two ago. The whole society was then vastly poorer in material terms, yet it was more orderly. That was because the vast majority of Americans come from individualist backgrounds and thus possessed more capacity to discipline themselves.

Today's high poverty areas, in contrast, are mostly inhabited by people originating from outside the Western world-chiefly blacks and Hispanics. In the non-West, social order depends mainly on external authority-pressure from local communities and customs as well as government. But when these groups come to the West, they encounter a society that is much freer in these senses. There is much less external enforcement of mores and much more reliance on internalized norms about good behavior. But the non-Western groups often lack that psychology. Thus when they come to America, they are liberated from both external and internal constraint. So social order declines even if incomes rise.

Academics blame black social problems on white oppression. By that logic, the problems should have been worst prior to the civil rights reforms in the 1960s. But in fact the opposite occurred. The collapse of the black family occurred mostly after civil rights were attained rather than before. Most blacks came from a highly collective society in Africa, then lived under slavery and Jim Crow in the South. Those structures kept social disorder at a low level. Before 1960, black levels of crime and female-headedness were not much higher than among whites. But blacks lost that structure after many migrated to the Northern cities in the last century, and especially after Jim Crow was abolished in the 1960s. So black social problems escalated even as opportunities broadened..$^{14}$

Similarly, Hispanic immigrants suffer much worse family decline after they come to America than they had in Mexico. ${ }^{15}$ Poor Hispanics, like most blacks,

13 Charles Murray, Coming Apart: The State of White America, 1960-2010 (New York: Crown Forum, 2012); Robert D. Putnam, Our Kids: The American Dream in Crisis (New York: Simon \& Schuster, 2015).

14 David Whitman, "The Great Sharecropper Success Story," The Public Interest (Summer 1991): 3-19.

15 OECD Family Database, downloaded June 20, 2016; Sara McLanahan and Christopher Jencks, "Was Moynihan Right?" EducationNext 15, no. 2 (Spring 2015), figure 1. 
have not yet replaced those older external controls with the internalized inhibitions of an individualist culture. Their problem is no longer oppression, but freedom.

\section{Is Integration Possible?}

The War on Poverty assumed that, as more adults progressed in the workplace, their children would get ahead through school. Education had long been America's chief ladder into the middle class. Policymakers imagined in the 1960s that, following civil rights, most blacks and Hispanics would graduate from high school, with many of them going on to college, as earlier groups such as the Irish and Italians had done.

But these hopes have mostly been disappointed. While Asians do well in school, most blacks and Hispanics do not, with proportionally far fewer getting through high school, and even fewer through college, compared to whites. Part of the reason is the disordered families just mentioned, but a deeper explanation is that schools take for granted the individualist temperament that most minority Americans lack. Teachers assume that students, even at a young age, are able to meet impersonal standards and compete for advancement. That prospect is chilling for youth who have been raised to think life is only about survival. To many Hispanic parents, Lionel Sosa writes, school evokes "awe” and "fear," and their children take on that attitude. A "wall" that is "made of culture," Earl Shorris writes, simply shuts most Hispanics off from the routine progress toward the American dream that earlier, European groups enjoyed. ${ }^{16}$

Even sympathetic observers have had to abandon the idea that today's poor are at all comparable to the European groups that preceded them. Racial integration remains a distant hope..$^{17}$ The likely reason today is no longer racial bias but a deep sense of cultural difference. Whites fear to associate with groups that, on average, do not display the inner-driven, moralistic temperament that allows strangers to trust each other in an individualist society.

Far more hopeful is the black middle class-those blacks who, despite origins in Africa and decades of exclusion, have become individualists

16 Earl Shorris, Latinos: A Biography of the People (New York: Norton, 1992), chap. 14; Lionel Sosa, The Americano Dream: How Latinos can Achieve Success in Business and In Life (New York: Dutton, 1998), chap. 7.

17 Nathan Glazer, "Black and White After Thirty Years," The Public Interest (Fall 1995): 61-79. 
themselves. They have embraced what Martin Luther King, Jr., called “assertive selfhood,"18 and that is the key to their advancement. They display the same temperament as most whites. Most middle-class whites already study and work alongside blacks like this, so living in the same neighborhoods becomes imaginable. America could be multiracial yet remain united provided all groups accept a basically individualist view of life.

If that goal remains distant, it is because cultural change is demanding. Whites must give up racist views that blacks are fundamentally different from themselves; polls, at least, suggest that the vast majority have already done so. ${ }^{19}$ The minority poor, however, have the tougher task of taking on the burdens of freedom. They must, that is, follow the black middle class in shouldering the inner and outer burdens of leading a free life. Then, at last, they can be at home in America.

\section{What To Do?}

Liberals usually say that government must do more to overcome poverty, while conservatives call for less. But since the 1960s, government has already tried each strategy, to little avail. When they are in power in Washington, Democrats have spent more on poverty, Republicans relatively less, but entrenched poverty remains. The reason is that neither strategy reaches to the nub of the problem - the tendency of the non-Western poor to assign power to outside forces rather than themselves. They are dependent not so much on government as on their entire environment. Merely for government to do more or less for them does not change that. For if government does more or less to help you, that only confirms the belief that change must come entirely from outside yourself.

External order must at least be restored in poor areas. Here there has been recent progress. The 1960s and 1970s were so permissive about crime and welfare that they fomented the breakdown of inner-city America. But since Reagan, the voters have insisted on tougher law enforcement, then putting more welfare recipients to work, and finally tougher standards in the schools. There

18 Quoted in Anthony Lewis, "A New National Scripture," New York Times Magazine, January 18, $2009,10$.

19 Howard Shuman, Charlotte Steeh, and Lawrence Bobo, Racial Attitudes in America: Trends and Interpretation (Cambridge, MA: Harvard University Press, 1985). 
is progress on all these fronts, although battles remain. Recent work, education, and training programs have become more paternalist, or directive, telling clients what they must do to get ahead. Such efforts are more effective than just offering clients benefits and choices. Such programs can be supportive, but essential norms are enforced. It's "help and hassle.” One reason this approach works is that non-Western culture is strongly deferential to authority. Once society shows a willingness to enforce norms, the poor generally comply.

But ultimately, the solution to poverty lies with inner, not outer authority. Dependent people must finally take charge of their own fate rather than waiting more passively for outward change. Whether the poor can do that is central to whether they get ahead. ${ }^{20}$ The best charter schools promote that stance. They teach children the norms of good behavior that individualists need in a free society, but students also learn how to make the many choices that a free society leaves open to them. ${ }^{21}$ They become more inwardly bound, the better to be more outwardly free, and that is the American way.

20 James S. Coleman, "Equal Schools or Equal Students?" The Public Interest, no.4 (Summer 1966): 70-75; Harry Eckstein, "Civic Inclusion and Its Discontents," Daedalus 113, no. 4 (Fall 1984): 107-45.

21 David Whitman, Sweating the Small Stuff: Inner-City Schools and the New Paternalism (Washington, DC: Thomas B. Fordham Institute, 2008); David Leonhardt, "Schools That Work," New York Times, November 6, 2016, SR2; Robert Pondiscio, How the Other Half Learns: Equality, Excellence, and the Battle Over School Choice (New York: Avery, 2019). 